\title{
Review: Komposit Polimer Pektin dalam Sistem Penghantaran Obat
}

\section{Devi Puspita Sari ${ }^{1}$, Pramulani Mulya Lestari ${ }^{1}$, Nining Nining ${ }^{*}, 2$}

${ }^{1}$ Program Studi Sarjana Farmasi, Fakultas Farmasi dan Sains, Universitas Muhammadiyah Prof. DR. HAMKA, DKI Jakarta, Indonesia 2Unit Bidang IImu Teknologi Farmasi, Fakultas Farmasi dan Sains, Universitas Muhammadiyah Prof. DR. HAMKA, DKI Jakarta, Indonesia

*Email: nining@uhamka.ac.id

(Submit 11/11/2021, Revisi 26/11/2021, Diterima 14/12/2021, Terbit 12/2/2022)

\section{Abstrak}

Pektin merupakan polisakarida yang berlimpah di alam dan memiliki kegunaan yang menjanjikan dalam bidang farmasi. Pektin tahan terhadap enzim pencernaan namun gel pektin dapat membengkak dalam media berair dan sejumlah kecil senyawa dapat dilepaskan ke saluran gastrointestinal. Masalah ini dapat diatasi dengan mengembangkan komposit pektin yang diperoleh dari penggabungan polimer pektin dengan polimer lain. Artikel ini membahas tentang interaksi pektin dengan polimer lain dalam berbagai sistem penghantaran obat. Metode yang digunakan dalam artikel review adalah dengan meninjau jurnal ilmiah yang diterbitkan secara nasional dan internasional yang diperoleh dari Google, Google Scholar, Pubmed dan Science Direct dengan kata kunci menggunakan Bahasa Indonesia dan Bahasa Inggris berupa "komposit polimer", "komposit pektin", "pektin”, "sistem penghantaran obat", "pectin”, "pectin composite", "polimer composite", dan "drug delivery system". Literatur yang digunakan kemudian dilakukan skrining jurnal dengan kriteria inklusi yaitu waktu terbit dengan rentang tahun 2011-2021. Dari beberapa penelitian terkait, sistem penghantaran yang telah dikembangkan dan dilaporkan berupa film, hidrogel, sistem partikulat dan tablet. Polimer lain seperti alginat, protein, kitosan, gelatin dan pati diketahui dapat memperbaiki sifat pektin sehingga komposit pektin dapat digunakan sebagai penghantaran obat terkontrol. Dengan demikian, pengembangan sistem penghantaran obat lainnya dengan komposit pektin menjadi peluang dan tantangan di masa yang akan datang.

Kata kunci: Pektin, Komposit Pektin, Sistem Penghantaran Obat

\section{Pendahuluan}

Pektin merupakan jenis serat struktural yang terletak di dinding sel primer dan lapisan intraseluler sel tanaman terutama pada buah-buahan, seperti jeruk, lemon, apel dan sebagainya1. Selama bertahun-tahun, pektin telah banyak digunakan dalam industri makanan dan minuman sebagai bahan pembentuk gel, bahan pengental, bahan penstabil dan bahan pengemulsi2, pektin juga memiliki kegunaan dalam bidang farmasi untuk perlindungan dan pelepasan zat aktif yang terkontrol, karena sifat biokompatibilitas yang sangat baik, sensitivitas $\mathrm{pH}$, biodegradabilitas, 
dan non toksisitas. Selain itu pektin juga tahan terhadap enzim protease dan amilase yang aktif dalam saluran pencernaan, dan mudah difermentasi mikroflora usus sehingga membuatnya cocok untuk pengiriman obat ke usus besar3. Namun gel pektin membengkak dalam media berair dan sejumlah kecil senyawa (obat) dapat dilepaskan ke saluran gastrointestinal. Dalam mengatasi masalah tersebut, telah dikembangkan penggabungan pektin dengan polimer lain untuk membentuk gel pektin yang kuat, dan untuk pelepasan obat di usus besarr ${ }^{4}$.

Komposit pektin merupakan penggabungan polimer pektin dengan polimer lain untuk menghasilkan material baru dengan sifat-sifat fungsional yang lebih baik. Dalam hal penghantaran obat, komposit polimer dapat digunakan sebagai matriks pelindung, mendorong pelepasan terkontrol, dan meningkatkan bioavailabilitas dan stabilitas obat yang dimuat. Berbagai biopolimer yang sangat penting dalam industri farmasi termasuk alginat, protein, kitosan, gelatin dan pati. Alginat dan protein berperan dalam sistem penghantaran obat ${ }^{5,6}$. Kitosan banyak digunakan untuk aplikasi biomedis seperti rekayasa jaringan, sistem penghantaran obat, meningkatkan bioavabilitas obat ${ }^{7,8}$. Gelatin karena kemampuan gelasinya merupakan bahan baku yang sangat menarik untuk pembuatan hidrogel sehingga dapat digunakan sebagai bahan biodegradable dalam bidang medis dan farmasi ${ }^{9}$, sedangkan polimer pati telah banyak digunakan untuk penghantaran obat karena dapat meningkatkan kelarutan dan stabilitas obat, mengurangi toksisitas dan efek samping obat, serta biokompatibilitas dan stabilitas penyimpanan yang sangat baik ${ }^{10}$. Tujuan dari artikel review ini untuk memahami interaksi antara campuran pektin dengan polimer yang berbeda dalam menghasilkan material baru dengan sifat-sifat fungsional yang lebih baik sehingga menjadi daya tarik komersial di pengembangan formulasi dengan stabilitas yang lebih baik atau tekstur yang lebih diinginkan, serta dapat mengurangi penggunaan biopolimer sintetik yang lebih mahal dan menggantinya dengan yang lebih murah dan aman ${ }^{11}$.

\section{Metode}

Pencarian melalui database seperti Google, Google Scholar, Pubmed dan Science Direct dengan kata kunci "komposit polimer", "komposit pektin", "pektin", "sistem penghantaran obat", "pectin", "pectin composite", "polimer composite", dan "drug delivery system".

\begin{tabular}{|l|l|}
\hline \multicolumn{2}{|c|}{ Skrining awal $=105$ artikel } \\
\cline { 2 - 2 } & $\begin{array}{l}\text { Eksklusi }(\mathrm{n}=35) \\
\text { Komposit polimer tidak berkaitan dengan pektin } \\
(\mathrm{n}=20) \\
\text { Komposit pektin yang tidak berkaitan dengan } \\
\text { sistem penghantaran obat }(\mathrm{n}=15)\end{array}$ \\
\cline { 2 - 3 }
\end{tabular}

Artikel yang direview $=70$ artikel

Gambar 1. Diagram alir penyusunan artikel review 
Dilakukan penelusuran literatur yang didapat dari jurnal ilmiah yang diterbitkan secara nasional dan internasional, pencarian jurnal dilakukan secara online melalui mesin pencari seperti Google, Google Scholar, Pubmed dan Science Direct dengan kata kunci menggunakan Bahasa Indonesia dan Bahasa Inggris berupa "komposit polimer", "komposit pektin", "pektin", "sistem penghantaran obat", "pectin", "pectin composite", "polimer composite", dan "drug delivery system". Literatur yang akan digunakan kemudian dilakukan skrining jurnal dengan kriteria inklusi yaitu waktu terbit dengan rentang tahun 2011-2021. Berdasarkan hasil penelusuran menggunakan kata kunci sebagaimana telah disebutkan, diperoleh bagan hasil penelusuran artikel sebagaimana terlampir pada Gambar 1.

\section{Hasil dan Pembahasan Struktur Kimia}

Pektin merupakan polisakarida dinding sel yang sangat penting pada tanaman tingkat tinggi. Terletak di lamela tengah dan primer dinding sel tanaman dikotil. Pektin berperan dalam pertumbuhan serta perkembangan tanaman ${ }^{12}$. Struktur pektin sulit ditentukan karena komposisinya bervariasi yang dipengaruhi oleh sumber tanaman dan kondisi ekstraksi ${ }^{13}$. Pektin juga dapat berubah karena varietas tanaman yang berbeda dan tingkat kematangan serta berbagai prosedur teknologi pada kualitas pektin ${ }^{14}$. Saat ini berdasarkan hasil penelitian yang telah dilakukan menyatakan bahwa pektin adalah polisakarida heterogen dengan tiga domain struktural utama yaitu Homogalakturonan dengan dua cabang Rhamnogalakturonan yang dinyatakan sebagai RG-I dan RG-II. Seperti yang tertera pada

\section{Gambar 2.}

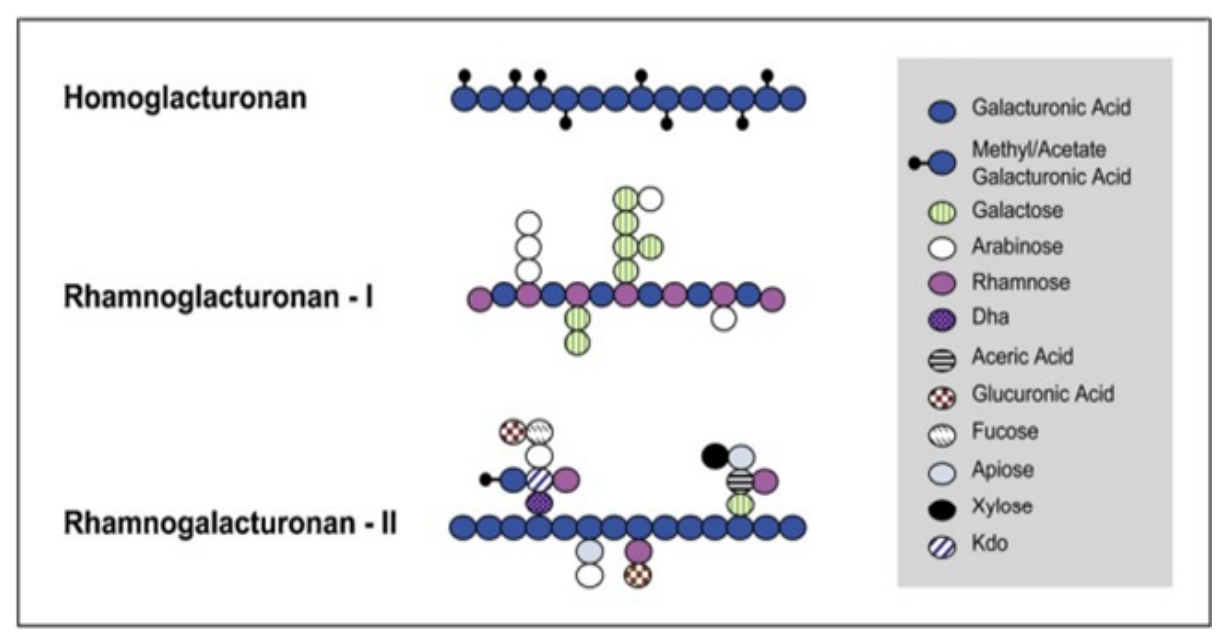

Gambar 2. Struktur Pektin [12].

Homogalakturonan merupakan polimer tunggal yang tersusun dari asam D-galakturonat yang dapat diesterifikasi atau dimetilasi. Rhamnogalakturonan I adalah molekul yang dibentuk oleh pengulangan asam rhamnose-galakturonat disakarida, dengan rantai samping galaktosa dan arabinosa. Sedangkan rhamnogalakturonan II merupakan rantai homogalakturonan dengan rantai samping yang lebih kompleks ${ }^{12}$. 


\section{Sumber Pektin}

Tabel 1. Sumber pectin

\begin{tabular}{cccc}
\hline Sumber pektin & $\begin{array}{c}\text { Persentase jumlah } \\
\text { pektin }\end{array}$ & $\begin{array}{c}\text { Derajat Esterifikasi } \\
\mathbf{( \% )}\end{array}$ & Literatur \\
\hline Jambu mete pomace & $10-25$ & $28-46$ & {$[15]$} \\
Lemon & 14,36 & 84,54 & {$[16]$} \\
Tangerin & 12,82 & 78,88 & {$[16]$} \\
Kulit jeruk & 14,08 & 84,68 & {$[16]$} \\
Kulit pisang & $15,89-24,08$ & $63,15-72,03$ & {$[17)$} \\
Kulit apel pomace & 10,91 & 58,44 & {$[17]$} \\
Pulp gula bit & $5,5-17,2$ & $42-71$ & {$[18]$} \\
Pulp kentang & 14,34 & 37,45 & {$[19]$} \\
Limbah nangka & $8,94-14,14$ & Tidak ditampilkan & {$[20]$} \\
Limbah tomat & $15,1-21,1$ dan $31-$ & $84,5-89 \%$ dan $76,9-$ & {$[21]$} \\
\hline
\end{tabular}

Pektin hampir dapat ditemukan pada semua jenis tanaman sebagaimana terlampir pada Tabel 1, terutama pada keluarga citrus, seperti jeruk, lemon, jeruk bali dan apel. Pektin juga terdapat pada buah jambu mete pomace sekitar $10-25 \%$ dengan kondisi ektraksi yang berbeda ${ }^{15}$. Selain itu pektin terdapat pada lemon, tangerin dan kulit jeruk masing-masing adalah 14,36; 12,82 dan $14,08 \%{ }^{16}$. Kandungan pektin dalam kulit buah pisang dengan jenis yang berbeda $15,89-24,08 \%$ dan kulit apel pomace $10,91 \%{ }^{17}$.

Pemanfaatan produk sampingan yang diperoleh dari industri menjadi suatu hal yang menarik sebagai sumber alternatif penghasil pektin dalam beberapa tahun terakhir, seperti pada pulp gula bit yang dapat menghasilkan pektin sebesar 5,5-17,2\%, dilaporkan bahwa pektin dapat meningkat seiring dengan penurunan $\mathrm{pH}$ larutan ekstraksi ${ }^{18}$. Yang et al., (2018) meneliti tentang pulp kentang berdasarkan perbedaaan jenis asam dengan hasil rendemen pektin tertinggi yaitu $14,34 \%{ }^{19}$. Pektin juga dapat diperoleh dari limbah nangka sebesar 8,94-14,14\% berdasakan berat kering dengan perbedaan kondisi ekstraksi dan jenis pelarut, namun kelarutan yang dihasilkan lebih rendah dibandingkan dengan pektin komersial ${ }^{20}$. Pada penelitian Grassino et al., (2016) memanfaatkan limbah tomat untuk menghasilkan pektin dengan metode ekstraksi yang berbeda yaitu metode ekstraksi konvensional dan ultrasonik, hasil penelitian menunjukkan bahwa limbah tomat menggandung pektin sekitar $15,1-21,1 \%$ dengan metode ekstraksi konvensional dan 31-35,7\% dengan metode ekstraksi ultrasonik ${ }^{21}$. Berdasarkan jumlah perolehan pektin pada berbagai sumber bahan, kandungan terbesar dapat diperoleh dari limbah tomat dan kulit pisang.

\section{Penggolongan Pektin}

Berdasarkan Derajat Esterifikasi (DE) pektin dibedakan menjadi dua golongan, yaitu pektin dengan kadar metoksil tinggi (HM) dan pektin dengan kadar metoksil rendah (LM). 
Nilai Derajat Esterifikasi (DE) pada pektin dengan kadar metoksil tinggi yaitu lebih dari $50 \%$. Pektin metoksil tinggi (HM) memerlukan kondisi yang spesifik dalam membentuk gel, seperti $\mathrm{pH}(3-6)$, adanya padatan terlarut seperti sukrosa, serta suhu yang lebih tinggi dibandingkan dengan pektin metoksil rendah $(L M)^{22}$. Fungsi sukrosa dalam pembentukan gel adalah untuk meningkatkan viskositas dan proses gelasi ${ }^{23}$. Secara umum pektin metoksil tinggi (HM) dapat larut dalam air panas serta bersifat termal reversibe ${ }^{24}$.

Pektin dengan kadar metoksil rendah (LM) mempunyai nilai Derajat Esterifikasi kurang dari $50 \%$. Pektin metoksil rendah (LM) tidak tergantung pada kandungan gula dan secara kimiawi lebih stabil terhadap kelembaban serta panas dibandingkan dengan pektin kadar metoksil tinggi (HM). Dengan adanya sejumlah kalsium atau kation divalen, pektin metoksil rendah (LM) dapat membentuk gel dan proses pembentukan gel ini dapat dengan mudah dibalik dengan menambahkan ion monovalen seperti natrium $(\mathrm{Na}+)$ dan kalium $(\mathrm{K}+)$. Tekstur gel pektin metoksil rendah dapat dikontrol dengan menyesuaikan rasio antaran kalsium dan pektin. Kandungan pektin yang tinggi dengan kalsium yang relatif sedikit akan memberikan gel yang elastis, sedangkan penggunaan lebih banyak kalsium dengan pektin minimum akan menghasilkan produk gel yang mudah hancur, mungkin dengan beberapa sineresis ${ }^{25}$. Meskipun gula tidak penting untuk pembentukan gel pada pektin metoksil rendah, sejumlah kecil gula cenderung menurunkan sineresis dan menambah kekuatan yang diinginkan dari gel ini, serta dengan adanya gula jumlah kalsium yang dibutuhkan untuk membentuk gel berkurang. Di sisi lain, konsentrasi gula yang tinggi mengganggu pembentukan gel karena dehidrasi gula mendukung ikatan hidrogen dan mengurangi ikatan silang dengan gaya ion divalen ${ }^{26}$.

\section{Komposit Pektin}

Gugus fungsi dalam struktur pektin dapat berinteraksi dengan berbagai molekul, komposit pektin merupakan penggabungan polimer pektin dengan polimer lain untuk menghasilkan material baru dengan sifat-sifat fungsional yang lebih baik. Dalam hal penghantaran obat, komposit polimer dapat digunakan sebagai matriks pelindung, mendorong pelepasan terkontrol, dan meningkatkan bioavailabilitas dan stabilitas obat yang dimuat, seperti yang telah diuraikan pada Tabel 2.

Tabel 2. Komposit pektin dalam sistem penghantaran obat

\begin{tabular}{|c|c|c|c|c|c|c|}
\hline Komposit & $\begin{array}{c}\text { Rasio } \\
\text { Campuran }\end{array}$ & $\begin{array}{c}\text { Fungsi } \\
\text { Komposit }\end{array}$ & Zat Aktif & $\begin{array}{l}\text { Bentuk } \\
\text { Sediaan }\end{array}$ & $\begin{array}{c}\text { Metode } \\
\text { Pembuatan }\end{array}$ & $\begin{array}{c}\text { Literat } \\
\text { ur }\end{array}$ \\
\hline $\begin{array}{l}\text { Alginat- } \\
\text { pektin }\end{array}$ & $\begin{array}{l}\text { 100:0, } \\
\text { 80:20, } \\
\text { 70:30, } \\
60: 30\end{array}$ & $\begin{array}{c}\text { Zat } \\
\text { pembawa }\end{array}$ & $\begin{array}{l}\text { Asam } \\
\text { folat }\end{array}$ & Mikrokapsul & Ekstrusi & {$[28]$} \\
\hline $\begin{array}{l}\text { Alginat- } \\
\text { pektin }\end{array}$ & $\begin{array}{c}\text { 100:0\%, } \\
\text { 75:25\%, } \\
\text { 50:50\%, } \\
\text { 25:75\% dan } \\
\text { 0-100\% }\end{array}$ & $\begin{array}{c}\text { Agen } \\
\text { pembentuk } \\
\text { film }\end{array}$ & - & Edible film & Solvent casting & [29] \\
\hline
\end{tabular}




\begin{tabular}{|c|c|c|c|c|c|c|}
\hline $\begin{array}{l}\text { Pektin- } \\
\text { alginat }\end{array}$ & $1: 1$ & $\begin{array}{c}\text { Agen } \\
\text { pembentuk } \\
\text { film }\end{array}$ & - & Film & Solvent casting & [30] \\
\hline $\begin{array}{l}\text { Pektin- } \\
\text { alginat }\end{array}$ & $4: 1 \%$ & Zat pembawa & Cisplatin & Mikrosfer & $\begin{array}{c}\text { Elektrospray dan } \\
\text { pelapisan } \\
\text { polielektrolit } \\
\text { multilayer }\end{array}$ & [31] \\
\hline $\begin{array}{l}\text { Alginat- } \\
\text { pektin }\end{array}$ & $80: 20$ & Zat pembawa & $\begin{array}{c}\text { Polifenol \& } \\
\beta \text {-karoten }\end{array}$ & Mikrokapsul & Gelasi ionik & [32] \\
\hline $\begin{array}{l}\text { Pektin- } \\
\text { kitosan }\end{array}$ & $\begin{array}{c}0,5 \%, 1 \% \\
2 \%\end{array}$ & Zat pembawa & $\begin{array}{c}\text { Mesalamin } \\
\text {, kurkumin } \\
\text { dan } \\
\text { progestero } \\
n\end{array}$ & Hidrogel & $\begin{array}{l}\text { Ikatan silang } \\
\text { (cross-linking) }\end{array}$ & [37] \\
\hline $\begin{array}{l}\text { Pektin- } \\
\text { kitosan }\end{array}$ & $\begin{array}{c}\text { 2:1, 3:1, 4:1, } \\
\text { 5:1 } \\
\text { (coating). } \\
\text { 1.2:1, } 2: 1 \\
\text { (blending). }\end{array}$ & Zat pembawa & $\begin{array}{l}\text { Bovine } \\
\text { Serum } \\
\text { Albumin } \\
\text { (BSA), } \\
\text { albumin } \\
\text { dari putih } \\
\text { telur }\end{array}$ & Nanopartikel & $\begin{array}{l}\text { Coating dan } \\
\text { blending }\end{array}$ & [38] \\
\hline $\begin{array}{l}\text { Pektin- } \\
\text { kitosan }\end{array}$ & $5: 5 \%$ & $\begin{array}{c}\text { Agen } \\
\text { pembentuk } \\
\text { film }\end{array}$ & $\begin{array}{c}\text { Dextromet } \\
\text { horphan } \\
\mathrm{Hbr}\end{array}$ & $\begin{array}{c}\text { Orally } \\
\text { Dissolving Film } \\
\text { (ODF) }\end{array}$ & Solvent casting & [62] \\
\hline $\begin{array}{l}\text { Pektin- } \\
\text { kitosan }\end{array}$ & $\begin{array}{c}3: 1 \%, 3: 2 \%, \\
5: 1 \%, 5: 2 \%\end{array}$ & Zat pembawa & Hesperidin & Hidrogel & Desain faktorial & [46] \\
\hline $\begin{array}{l}\text { Pektin- } \\
\text { kitosan }\end{array}$ & $1: 4$ & Matriks & $\begin{array}{l}\text { Lidokain } \\
\mathrm{HCl}\end{array}$ & Hidrogel & $\begin{array}{l}\text { Ikatan silang } \\
\text { (cross-linking) }\end{array}$ & [64] \\
\hline $\begin{array}{l}\text { Kitosan- } \\
\text { pektin }\end{array}$ & $1,5 \%: 2 \%$ & $\begin{array}{c}\text { Bahan } \\
\text { penyalut }\end{array}$ & $\begin{array}{c}5- \\
\text { fluorourasi } \\
\text { I }\end{array}$ & Mikrogel & $\begin{array}{l}\text { Ikatan silang } \\
\text { (cross-linking) }\end{array}$ & [67] \\
\hline $\begin{array}{l}\text { Kitosan- } \\
\text { pektin }\end{array}$ & $60: 40$ & $\begin{array}{c}\text { Bahan } \\
\text { penyalut }\end{array}$ & Mesalamin & Tablet salut & $\begin{array}{c}\text { Pengeringan } \\
\text { semprot (spray } \\
\text { drying) }\end{array}$ & [69] \\
\hline $\begin{array}{l}\text { Kitosan- } \\
\text { pektin }\end{array}$ & $1: 5$ & Zat pembawa & Teofillin & $\begin{array}{c}\text { Tablet salut } \\
\text { enterik }\end{array}$ & Granulasi basah & [70] \\
\hline $\begin{array}{l}\text { Kitosan- } \\
\text { pektin }\end{array}$ & $1: 1$ & Zat pembawa & Tenofovir & Tablet vaginal & Kempa langsung & [68] \\
\hline $\begin{array}{l}\text { Kitosan- } \\
\text { pektin }\end{array}$ & $\begin{array}{c}1: 2,2: 3,1: 1 \\
3: 2,2: 1 \text { dan } \\
3: 1\end{array}$ & Bahan utama & - & Nanopartikel & Gelasi ionik & [65] \\
\hline $\begin{array}{l}\text { Pati- } \\
\text { pektin }\end{array}$ & $4: 1,1: 1,1: 4$ & Zat pembawa & $\begin{array}{c}\text { Natrium } \\
\text { diklofenak }\end{array}$ & Mikropartikel & $\begin{array}{l}\text { Ikatan silang } \\
\text { (cross-linking) }\end{array}$ & [60] \\
\hline $\begin{array}{l}\text { Pati- } \\
\text { pektin }\end{array}$ & $1: 1,1: 4$ & $\begin{array}{c}\text { Agen } \\
\text { pembentuk } \\
\text { film }\end{array}$ & - & Film & Solvent casting & {$[4]$} \\
\hline
\end{tabular}




\section{Pektin-Alginat}

Sistem pektin-alginat menjadi salah satu campuran gel yang telah banyak digunakan dalam berbagai penelitian. Sifat struktural dari kedua campuran gel ini bergantung pada rasio pektin-alginat, tingkat esterifikasi pektin, proporsi asam manuronat dan asam guluronat dari alginat. Struktur gel alginat dengan kandungan asam manuronat yang tinggi dan pektin yang memiliki derajat esterifikasi tinggi rentan terhadap pelepasan. Sebaliknya, alginat dengan kandungan asam guluronat yang tinggi mampu membentuk gel kaku yang kurang rentan terhadap pembengkakan dan erosi sehingga menyebabkan pelepasan lebih lambat dan efisiensi enkapsulasi yang lebih tinggi. Pektin dengan tingkat esterifikasi yang lebih tinggi menghasilkan struktur yang lebih lemah dibandingkan dengan tingkat esterifikasi yang lebih rendah ${ }^{27}$.

Penelitian Kiaei Pour et al., (2020) melaporkan bahwa biokomposit pektin-alginat dengan berbagai komposisi yang berbeda dapat menjadi pembawa mikrokapsul dalam saluran gastrointestinal dan usus, dimana hidrogel alginat yang dilapisi dengan pektin dengan rasio 70:30 menghasilkan perlindungan yang baik terhadap asam folat dibandingkan dengan hidrogel alginat tanpa pektin dalam kondisi lambung dan usus buatan ${ }^{28}$. Campuran pektin-alginat telah terbukti memberikan efek perlindungan yang baik sebagai matriks gel yang kuat di bawah kondisi asam ${ }^{27}$.

Kombinasi pektin-alginat juga dimanfaatkan dalam sediaan film komposit, campuran polisakarida tersebut dapat menghasilkan film yang homogen dan transparan, tanpa pori-pori dan retakan. Seiring dengan meningkatnya kandungan pektin, maka akan meningkatkan ketebalan film komposit. Hal ini berhubungan dengan sifat koloid senyawa dan interaksi antar komponen. Film dengan kandungan alginat yang lebih tinggi memiliki ketebalan yang lebih rendah ${ }^{29}$. Pada penelitian lainnya, Seixas et al., (2013) membuat biofilm yang terdiri dari alginat dan pektin menghasilkan film komposit homogen dan transparan, meningkatkan karakteristik fisiknya dengan aplikasi potensial dalam bidang farmasi sebagai pelapis obat ${ }^{30}$.

Banyak contoh telah dilaporkan dalam beberapa tahun terakhir. Hsu et al., (2013) telah mengembangkan dan mengevaluasi mikrosfer pektinat/alginat yang dilapisi dengan polimer Eudragit $\mathrm{S} 100$ untuk pengiriman cisplatin di usus besar, melalui teknik penyemprotan listrik, memperoleh mikrosfer dengan ukuran homogen dan $\mathrm{pH}$ independen di bawah simulasi kondisi lambung ${ }^{31}$. Selanjutnya, peneliti lain telah mengevaluasi mikroenkapsulasi polifenol dan karoten dari Taraxacum officinale L. dalam campuran biner pektin dan alginat yang memungkinkan profil pelepasan berkepanjangan dari senyawa-senyawa ini dalam cairan gastrointestinal buatan ${ }^{32}$.

\section{Pektin-Kitosan}

Pektin dan kitosan merupakan polisakarida yang dapat membentuk kompleks yang berguna untuk biodegradabilitas, biokompatibilitas dan non-toksisitas. Secara kimia, biopolimer ini dianggap sebagai polielektrolit, sehingga memiliki kemampuan untuk membentuk kompleks polielektrolit ${ }^{33}$. 
Kitosan merupakan basa lemah dan pektin merupakan asam lemah, sehingga dalam larutan, hal ini dapat menyebabkan terbentuknya gaya tarik elektrostatik antara gugus amino yang bermuatan positif $\left(\mathrm{NH}^{+3}\right)$ dalam kitosan dan gugus karboksil bermuatan negatif (-COO) dalam pektin ${ }^{34}$. Stabilitas kompleks pektin-kitosan ini terutama bergantung pada $\mathrm{pH}$, kerapatan muatan, konsentrasi kedua polimer dan kondisi ionik medium. Selain itu, suhu, konsentrasi molekul tertentu, kondisi lingkungan memainkan peran penting dalam stabilitas campuran gel ini ${ }^{35,36}$.

Kompleks polielektrolit ini memiliki banyak kegunaan dalam bidang farmasi, terutama sebagai sarana penghantaran obat ${ }^{37}$ dan penghantaran obat khusus usus besar ${ }^{38}$. Ketertarikan pada sistem ini untuk pelepasan obat yang terkontrol terletak pada kenyataan bahwa kedua polimer memiliki kapasitas untuk melindungi obat agar tidak dilepaskan di saluran usus bagian atas dan menghantarkannya ke usus besar ${ }^{39}$.

\section{Pektin-Protein}

Interaksi antara protein dan polisakarida sebagai dua biopolimer dapat secara luas dikategorikan ke dalam dua kondisi, yaitu saling tolak-menolak dan tarik-menarik, tergantung pada sifat biopolimer, konsentrasi, serta kondisi larutan (seperti $\mathrm{pH}$, kekuatan ion, suhu). Sebagai hasil dari interaksi tersebut, campuran proteinpolisakarida ada dalam dua fase yang berbeda, baik pemisahan fase asosiatif atau pemisahan fase segregatif. Ketika protein dan polisakarida membawa muatan yang berlawanan, kedua polimer tersebut dapat membentuk fase larut (sistem fase tunggal) atau endapan tidak larut (sistem dua fase). Ketika protein dan polisakarida dengan muatan sejenis, keduanya dianggap sebagai biopolimer yang saling tolak-menolak. Dalam keadaan seperti ini, kedua biopolimer dapat berdampingan dalam fase tunggal pada konsentrasi rendah, sedangkan pada konsentrasi yang lebih tinggi mulai terjadi pemisahan fase ${ }^{40}$.

Jenis interaksi lain dapat terjadi antara protein dan polisakarida, seperti ikatan kovalen yang dapat membentuk struktur yang sangat stabil serta interaksi non-kovalen seperti gaya elektrostatik, hidrofobik, hidrogen, dan van der Waals ${ }^{41}$. Dalam penelitian Chang, C et al., (2017), pektin diaplikasikan sebagai bahan penyalut untuk meningkatkan stabilitas fisikokimia nanopartikel natrium kaseinat/zein. Hasil penelitian menunjukkan bahwa penyalut pektin tidak hanya meningkatkan kemampuan enkapsulasi kurkumin dalam nanopartikel natrium kaseinat/zein tetapi juga memberikan pelepasan terkontrol dalam kondisi gastrointestinal. Oleh karena itu, pektin efektif untuk digunakan dalam penghantaran obat ${ }^{42}$.

Faktor fisikokimia yang beragam dapat mempengaruhi pembentukan dan stabilitas kompleks seperti $\mathrm{pH}$, kekuatan ionik, rasio pektin ke protein, muatan pektin dan protein, dan berat molekul, sehingga interaksi dominan dikaitkan dengan ikatan ion dan kerapatan muatan sangat menentukan dalam pembentukan kompleks. Parameter seperti penurunan kerapatan muatan pektin melalui esterifikasi parsial gugus karboksil, peningkatan kekuatan ionik atau penurunan $\mathrm{pH}$ dapat mengurangi kemampuan interaksi antara biopolimer $\mathrm{ini}^{43}$. 


\section{Pektin-Gelatin}

Gelatin merupakan salah satu biopolimer pangan yang banyak diteliti. Interaksi antara gelatin dan pektin telah dilaporkan oleh beberapa penulis. Berdasarkan penelitian Huang, S et al., (2020) menunjukkan bahwa kalsium dapat meningkatkan titik leleh dan viskositas gel, begitupun dengan kekerasan gel, kalsium yang berlebihan menghasilkan struktur gel yang longgar dan rapuh. Hal ini menunjukkan bahwa interaksi antara kedua biopolimer tersebut dalam hal kohesivitas dan kerapuhan bergantung dengan rasio pektin terhadap gelatin ${ }^{47}$. Beberapa peneliti menetapkan bahwa sifat reologi partikel hidrogel dipengaruhi oleh parameter seperti bentuk partikel, ukuran dan distribusi ukuran $^{48,49,50}$.

Pada penelitian Gupta et al., (2014) mengevaluasi reaksi pengikatan silang untuk pembentukan hidrogel gelatin dan pektin, menyimpulkan bahwa faktor-faktor seperti waktu reaksi, suhu reaksi, $\mathrm{pH}$ reaksi dan komposisi mempengaruhi secara langsung interaksi antara polimer ini ${ }^{51}$. Interaksi gelatin/pektin telah menjadi fokus penelitian dalam bidang farmasi, sebagai komposit untuk penghantaran obat yang terkontrol ${ }^{52}$, mikroenkapsulasi agen bioaktif sebagai likopen ${ }^{53}$, dan komposit untuk penyembuhan luka ${ }^{54}$.

\section{Pektin-Pati}

Sifat reologi, fisik dan kimia dari campuran ini telah dipelajari secara luas. Pada penelitian Gałkowska et al., (2013) mengevaluasi pasting, reologi dan sifat tekstur dari campuran pektin metoksil tinggi, sukrosa, dan pati kentang ikatan silang (Dipati Fosfat Terasetilasi dan Dipati Adipat Terasetilasi) yang digunakan untuk menghasilkan pasta dan gel. Pengaruh konsentrasi pati pada parameter suhu pasting dari sistem patipektin-sukrosa tergantung pada jumlah pati yang ditambahkan dan jenis pati yang dimodifikasi. Sifat elastis diamati pada sistem pati-pektin-sukrosa dengan meningkatkan konsentrasi pati. Sistem campuran tampak lebih kaku selama ekstrusi daripada gel pati saja, dengan nilai parameter tekstur yang semakin meningkat dengan bertambahnya konsentrasi pati ${ }^{55}$.

Pada penelitian Ma et al., (2019) mengevaluasi pengaruh konsentrasi pektin terhadap sifat pasta dan reologi pati jagung. Telah dilaporkan bahwa peningkatan konsentrasi pektin mempengaruhi viskositas sistem komposit, hal ini menunjukkan bahwa pektin dapat meningkatkan stabilitas pasta dan menghambat retrogradasi jangka pendek ${ }^{56}$. Peneliti lain mengevaluasi campuran pektin dan pati yang berbeda dengan menggunakan natrium trimetafosfat sebagai cross linker. Hasil yang diperoleh, penggunaan cross linker memiliki pengaruh yang cukup besar pada sifat reologi dan fisikokimia gel dan penelitian mengungkapkan bahwa ikatan silang antara polisakarida ini dapat terjadi dalam sistem polimer campuran ${ }^{57}$.

Mengenai penggunaan farmasi campuran pati/pektin, penggunaan polimer untuk pengiriman obat terkontrol juga telah dipelajari58. Peneliti Liu (2014) mengembangkan bahan komposit untuk pengiriman asam askorbat menggunakan campuran pati/pektin, melalui teknik pengeringan semprot. 
Efisiensi enkapsulasi dan profil pelepasan bergantung pada rasio pati/pektin dan juga berdampak pada distribusi ukuran mikropartikel, semakin kecil ukuran partikel maka tingkat pelepasan obat semakin meningkat karena rasio luas permukaan terhadap volume meningkat ${ }^{59}$. Peneliti lain juga telah mempelajari pelepasan obat diklofenak dalam matriks pati dan pektin ${ }^{60}$.

\section{Aplikasi dalam Sistem Penghantaran Obat Film}

Beberapa peneliti telah melakukan penelitian mengenai sediaan film dengan menggunakan komposit pektin, seperti pada penelitian Rezvanian et al., (2017) yang mengembangkan hidrogel komposit film dari campuran natrium alginat dan pektin yang dimuat dengan simvastatin dan menghubungkannya dengan $\mathrm{CaCl} 2$ digunakan sebagai pembalut luka. Ikatan silang meningkatkan profil mekanik dan kapasitas penyerapan luka dari dressing. Film hidrogel mampu mempertahankan integritas fisiknya selama penggunaan. Analisis termal menegaskan bahwa proses ikatan silang meningkatkan stabilitas termal film hidrogel. Pelepasan simvastatin yang lambat dan berkelanjutan diperoleh dari film ikatan silang dan uji sitotoksisitas in vitro menunjukkan bahwa film hidrogel tidak beracun ${ }^{61}$.

Pada penelitian Seixas et al., (2013) juga melaporkan biofilm yang dibuat dengan campuran pektin dan alginat menunjukkan sifat yang lebih baik jika dibandingkan dengan film yang dibuat dari polimer murni. Film komposit yang dihasilkan bersifat transparan dan homogen. Zat pengikat silang pada karakteristik film berkontribusi pada penurunan kelarutan dan permeabilitas terhadap uap air, selain memberikan peningkatan ketahanan material ${ }^{30}$.

Pada laporan lainnya, telah dikembangkan film dengan kombinasi matriks pektinkitosan menggunakan plasticizer eugenol dan asam oleat serta dextromethorphan $\mathrm{Hbr}$ (DHF) sebagai model obat. Hasil penelitian menunjukkan bahwa karakteristik film DHFeugenol menghasilkan karakteristik film yang lebih baik jika dibandingkan dengan DHFasam oleat pada berbagai konsentrasi. Penambahan asam oleat sebagai plasticizer pada formula untuk film yang cepat larut dapat menghasilkan film dengan sifat mekanik yang baik dan memenuhi kriteria ${ }^{62}$.

Penelitian lain telah melakukan pengembangan film dari dispersi pati retrogradasi dan pektin sebagai penghantaran obat pada usus besar. Film diperoleh dari metode solvent casting dari dispersi pati retrogradasi dan pektin pada proporsi dan konsentrasi polimer yang berbeda dan dengan atau tanpa plasticizer. Studi in vitro menunjukkan bahwa film yang diperoleh dengan proporsi polimer yang sama memberikan ketahanan yang lebih tinggi terhadap kondisi saluran gastrointestinal. Pada media asam, keberadaan dan jenis plasticizer tidak berpengaruh nyata terhadap sifat disolusi. Film dengan plasticizer menunjukkan kerentanan yang lebih rendah terhadap pencernaan enzimatik, dipengaruhi oleh kandungan pati retrogradasi yang tinggi ${ }^{4}$.

\section{Hidrogel}

Hidrogel termoreversibel dari pektin-kitosan yang berikatan silang secara fisik telah diuji untuk menghantarkan mesalamin, 
kurkumin dan progesteron sebagai model obat. Studi in vitro menunjukkan bahwa rasio pektin yang lebih rendah menyebabkan laju pelepasan obat yang lebih lambat karena ukuran mesh yang lebih kecil yang timbul dari interaksi yang lebih kuat antara polielektrolit ${ }^{37}$.

Fahrurroji et al. (2017) telah memformulasikan hidrogel hesperidin menggunakan matriks gabungan kitosan-pektin, di mana efisiensi penjeratan tertinggi $(96,65 \%)$ dicapai dengan pektin 5\%, juga mukoadhesivitas yang lebih besar. Studi in vitro menunjukkan bahwa matriks hidrogel dapat mengontrol pelepasan hesperidin dengan laju pelepasan obat tertinggi dicapai oleh formula yang memiliki konsentrasi pektin tertinggi dalam media yang mengandung $2 \%$ sekum tikus, melepaskan $56 \%$ obat. Hal ini membuktikan bahwa kombinasi polimer kitosan-pektin dapat digunakan sebagai matriks dalam pelepasan obat terkontrol pada organ target yaitu usus besar ${ }^{46}$.

Peneliti lain telah mengembangkan sel bakteri probiotik Lactobacillus plantarum yang dienkapsulasi dalam hidrogel pektin-pati dengan metode ekstrusi. Hasil menunjukkan bahwa sel yang dienkapsulasi tahan terhadap kondisi buruk dari simulasi saluran pencernaan dan larutan garam empedu dibandingkan dengan yang bebas. Hal ini membuat hidrogel pektin-pati menarik untuk dijadikan sebagai pembawa obat yang ideal dikemudian hari63.

Pengembangan desain lainnya telah dilakukan Long et al., (2019) yang memformulasi hidrogel kitosan-pektin cetak 3D untuk penghantaran obat lidokain hidroklorida sebagai perawatan luka. Profil pelepasan in vitro pada kondisi fisiologis menunjukkan ledakan pelepasan (burst release) dalam 1 jam, diikuti oleh pelepasan berkelanjutan dan terkontrol selama periode 4 jam. Proses penyembuhan luka dapat dipercepat dengan melepaskan molekul bioaktif dari pembalut luka yang dapat mempertahankan lingkungan penyembuhan sehingga mendukung regenerasi jaringan ${ }^{64}$.

\section{Sistem Partikulat}

Pada penelitian Baracat et al., (2012) mengembangkan sediaan mikrokapsul pektinkasein yang disiapkan dengan koaservasi kompleks untuk pelepasan obat terkontrol dengan asetaminofen sebagai model obat. Studi in vitro menunjukkan bahwa pelepasan asetaminofen dari mikrokapsul terjadi secara lambat dan mekanisme pelepasan obat dikendalikan oleh difusi mengikuti kinetika orde pertama. Pelepasan asetaminofen lebih besar pada cairan lambung dibandingkan dengan kondisi cairan usus, sehingga sistem polimer ini tampaknya sesuai untuk pelepasan asetaminofen yang berkepanjangan di seluruh saluran pencernaan ${ }^{45}$.

Peneliti lain juga telah mengembangkan nanopartikel kitosan-pektin yang disintesis menggunakan metode gelasi ionik spontan berair (aqueous spontaneous ionic gelation method). Studi in vitro menunjukkan bahwa partikel stabil dalam kisaran $\mathrm{pH} 3,5-6,0$ dan kehilangan stabilitas setelah 14 hari penyimpanan dalam media berair. Hal tersebut disebabkan karena tinggi muatan permukaan positif dari partikel, sifat bawaan dari polisakarida yang digunakan, dan disosiasi yang tidak berbahaya dari polielektrolit. Sistem ini menjadi suatu hal yang menarik untuk pengembangan nanopartikel kitosanpektin sebagai penyembuhan luka kronis ${ }^{65}$. 
Pada penelitian Islan et al., (2012) melaporkan enkapsulasi ciprofloxacin dalam mikrosfer alginat-pektin HM dengan pelepasan terkontrol pada saluran pencernaan. Mikrosfer alginat-pektin HM yang mengandung ciprofloxacin disiapkan dengan gelasi ionotropik menggunakan kalsium sebagai pengikat silang dalam kondisi asam. Studi in vitro menunjukkan bahwa sistem yang dikembangkan dalam penelitian tersebut berdasarkan alginat-pektin HM memberikan kondisi yang lebih baik untuk pengiriman oral ciprofloxacin, bukan hanya dapat mengurangi pelepasan obat dalam kondisi lambung, tetapi juga dapat melepaskan sebagian besar ciprofloxacin pada usus ${ }^{66}$.

Pada laporan lainnya, telah dikembangkan 5-fluorouracil menjadi mikrogel kitosan berlapis pektin untuk pemberian oral menggunakan polistiren substrat superhidrofobik. Studi in vitro menunjukkan bahwa sebagian besar obat dilepaskan dalam waktu 1 jam kecuali ketika menggunakan media pelarutan yang sangat asam $(1 \% \mathrm{HCl})$, dimana pelapisan pektin meningkatkan kontrol pelepasan 5-fluorouracil dalam medium asam selama hampir 4 jam. Dengan demikian, mikrogel kitosan berlapis pektin enkapsulasi 5fluorouracil menunjukkan pelepasan obat yang terkontrol. Hal ini membuktikan bahwa mikrogel yang diperoleh dapat berguna untuk mukosa dan pengobatan topikal, serta mikrogel berlapis pektin dapat digunakan untuk pengiriman spesifik situs agen antitumor ke sel kanker usus besar ${ }^{67}$.

\section{Tablet}

Campuran pektin-pati amilosa tinggi dievaluasi sebagai eksipien baru untuk matriks formulasi tablet. Campuran tersebut dapat dijadikan sebagai eksipien yang menjanjikan untuk tablet matriks yang dapat mengembang (swellable) yang dimaksudkan untuk mengontrol sistem penghantaran obat ${ }^{57}$. Cazorla-Luna et al., (2019) telah mengembangkan sediaan tablet vaginal dengan polimer mukoadhesif campuran kitosan-pektin untuk pencegahan penularan HIV melalui pelepasan terkontrol menggunakan tenofovir sebagai model obat. Studi in vitro menunjukkan bahwa kombinasi polimer kitosan dan pektin dapat memperlama pelepasan tenofovir hingga 96 jam. Selain itu campuran polimer pektin dan kitosan menghasilkan interaksi elektrostatik antara kedua polimer pada cairan vagina buatan, sehingga memperoleh sistem pembentuk gel yang kuat dan sangat terstruktur dalam media tersebut, mampu mempertahankan strukturnya selama proses swelling yang memastikan kepatuhan terapeutik ${ }^{68}$.

Pada penelitian Khurana et al., (2014) kombinasi kitosan-pektin sebagai film penyalut tablet untuk melepaskan mesilamin telah dilaporkan. Penelitian ini juga menggunakan penyalut eudragit sebagai pembanding. Studi in vitro menunjukkan bahwa tidak ada perbedaan yang signifikan antara pelepasan tablet salut kitosan-pektin dan tablet salut eudragit, namun tablet salut kitosan-pektin memiliki kekuatan daya lekat yang lebih baik dibandingkan tablet salut eudragit, serta campuran kitosan-pektin memberikan tekstur yang halus dan seragam pada tablet ${ }^{69}$.

Peneliti lain telah melakukan penelitian tentang kompleks polielektrolit (PEC) antara kitosan (polikation) \& pektin (polianion) serta mengembangkan tablet salut enterik untuk pengiriman usus besar menggunakan PEC. Komposisi optimal, 


\section{Kesimpulan}

Pektin merupakan polisakarida yang berlimpah di alam dan memiliki kegunaan yang menjanjikan dalam bidang farmasi. Pektin dapat berinteraksi dengan polimer lain sehingga menghasilkan komposit pektin yang dapat digunakan sebagai matriks penghantaran obat terkontrol, dan secara khusus menargetkan usus besar karena kapasitasnya untuk menahan kondisi asam. Sistem penghantaran yang telah dikembangkan dan dilaporkan berupa film, hidrogel, sistem partikulat dan tablet. Oleh karena itu, informasi yang terangkum dalam artikel ini dapat memberikan peluang untuk studi lebih lanjut mengenai pemanfaatan komposit pektin dalam berbagai sistem penghantaran obat.

\section{Daftar Pustaka}

1. Mudgil D. The Interaction Between Insoluble and Soluble Fiber. Dietary Fiber for the Prevention of Cardiovascular Disease: Fiber's Interaction between Gut Micoflora, Sugar Metabolism, Weight Control and Cardiovascular Health. Elsevier Inc.; 2017. 35-59 $p$

2. Raj AAS et al. A Review on Pectin: Chemistry due to General Properties of Pectin and its Pharmaceutical Uses. 2012;(01).

3. Martau GA, Mihai M, Vodnar DC. The use of chitosan, alginate, and pectin in the biomedical and food sector-biocompatibility, bioadhesiveness, and biodegradability. Polymers (Basel). 2019;11(11).

4. Bagliotti Meneguin A, Stringhetti Ferreira Cury B, Evangelista RC. Films from resistant starch-pectin dispersions intended for colonic drug delivery. Carbohydr Polym. 2014;99:140-9.

5. Jain D, Bar-Shalom D. Alginate drug delivery systems: Application in context of pharmaceutical and biomedical research. Drug Dev Ind Pharm. 2014;40(12):157684.

6. Elzoghby AO, Abo El-Fotoh WS, Elgindy NA. Casein-based formulations as promising controlled release drug delivery systems. J Control Release. 2011;153(3):206-16.

7. Cheung RCF, Ng TB, Wong JH, Chan WY. Chitosan: An update on potential biomedical and pharmaceutical applications. Vol. 13, Marine Drugs. 2015. 5156$5186 \mathrm{p}$.

8. Hanna DH, Saad GR. Encapsulation of ciprofloxacin within modified xanthan gumchitosan based hydrogel for drug delivery. Bioorg Chem. 2019;84(November 2018):115-24.

9. Parker NG, Povey MJW. Ultrasonic study of the gelation of gelatin : phase diagram , hysteresis and kinetics.

10. Yang J, Huang Y, Gao C, Liu M, Zhang X. Colloids and Surfaces B: Biointerfaces Fabrication and evaluation of the novel reduction-sensitive starch nanoparticles for controlled drug release. Colloids Surfaces B Biointerfaces. 2014;115:368-76.

11. Lara-Espinoza $C$, Carvajal-Millán E, Balandrán-Quintana $R$, López-Franco $Y$, Rascón-Chu A. Pectin and pectin-based composite materials: Beyond food texture. Molecules. 2018;23(4).

13. Kaya M, Sousa AG, Crépeau MJ, Sørensen SO, Ralet MC. Characterization of citrus pectin samples extracted under different conditions: Influence of acid type and $\mathrm{pH}$ of extraction. Ann Bot. 2014;114(6):1319-26. 
14. Geerkens $\mathrm{CH}$, Nagel A, Just KM, Miller-Rostek P, Kammerer DR, Schweiggert $\mathrm{RM}$, et al. Mango pectin quality as influenced by cultivar, ripeness, peel particle size, blanching, drying, and irradiation. Food Hydrocoll. 2015;51:241-51.

15. Yapo BM, Koffi KL. Extraction and characterization of highly gelling low methoxy pectin from cashew apple pomace. Foods. 2014;3(1):1-12.

16. Twinomuhwezi $\mathrm{H}$, Godswill AC, Kahunde D. Extraction and Characterization of Pectin from Orange (Citrus sinensis), Lemon (Citrus limon) and Tangerine (Citrus tangerina). Am J Phys Sci. 2020;1(1(2)):17-30.

17. Khamsucharit P, Laohaphatanalert K, Gavinlertvatana P, Sriroth K, Sangseethong K. Characterization of pectin extracted from banana peels of different varieties. Food Sci Biotechnol. 2018;27(3):623-9.

18. Ma S, Yu SJ, Zheng XL, Wang XX, Bao QD, Guo XM. Extraction, characterization and spontaneous emulsifying properties of pectin from sugar beet pulp. Carbohydr Polym. 2013;98(1):750-3.

19. Yang JS, Mu TH, Ma MM. Extraction, structure, and emulsifying properties of pectin from potato pulp. Food Chem. 2018;244(October 2017):197-205.

20. Begum R, Aziz MG, Uddin MB, Yusof YA. Characterization of Jackfruit (Artocarpus Heterophyllus) Waste Pectin as Influenced by Various Extraction Conditions. Agric Agric Sci Procedia. 2014;2:244-51.

21. Grassino AN, Brnčić M, Vikić-Topić D, Roca S, Dent M, Brnčić SR. Ultrasound assisted extraction and characterization of pectin from tomato waste. Food Chem. 2016;198:93-100.

22. Narasimman $P$, Sethuraman $P$. an Overview on the Fundamentals of Pectin. Int $J$ Adv Res. 2016;4(12):1855-60.

23. Giacomazza D, Bulone D, San Biagio PL, Marino R, Lapasin R. The role of sucrose concentration in self-assembly kinetics of high methoxyl pectin. Int J Biol Macromol. 2018;112:1183-90.

24. Zaid RM, Mishra P, Tabassum S, Wahid ZA, Sakinah AMM. High methoxyl pectin extracts from Hylocereus polyrhizus's peels: Extraction kinetics and thermodynamic studies. Int J Biol Macromol. 2019;141:1147-57.

25. Han W, Meng Y, Hu C, Dong G, Qu Y, Deng H, et al. Mathematical model of Ca2+ concentration, $\mathrm{pH}$, pectin concentration and soluble solids (sucrose) on the gelation of low methoxyl pectin. Food Hydrocoll. 2017;66:37-48.

26. Wan L, Yang Z, Cai R, Pan S, Liu F, Pan S. Calcium-induced-gel properties for low methoxyl pectin in the presence of different sugar alcohols. Food Hydrocoll. 2021;112(August 2020):106252.

27. Alborzi S, Lim LT, Kakuda Y. Release of folic acid from sodium alginate-pectinpoly(ethylene oxide) electrospun fibers under invitro conditions. LWT - Food Sci Technol. 2014;59(1):383-8.

28. Kiaei Pour P, Alemzadeh I, Vaziri AS, Beiroti A. Potential effects of alginate-pectin biocomposite on the release of folic acid and their physicochemical characteristics. J Food Sci Technol. 2020;57(9):3363-70.

29. Galus S, Lenart A. Development and characterization of composite edible films based on sodium alginate and pectin. J Food Eng. 2013;115(4):459-65.

30. Seixas FL, Turbiani FRB, Salomão PG, Souza RP, Gimenes ML. Biofilms composed of alginate and pectin: Effect of concentration of crosslinker and plasticizer agents. Chem Eng Trans. 2013;32(January):1693-8. 
31. Hsu FY, Yu DS, Huang CC. Development of pH-sensitive pectinate/alginate microspheres for colon drug delivery. J Mater Sci Mater Med. 2013;24(2):317-23.

32. Belščak-Cvitanovic A, Bušić A, Barišić L, Vrsaljko D, Karlović $S$, Špoljarić I, et al. Emulsion templated microencapsulation of dandelion (Taraxacum officinale L.) polyphenols and $\beta$-carotene by ionotropic gelation of alginate and pectin. Food Hydrocoll. 2016;57:139-52.

33. Jindal M, Kumar V, Rana V, Tiwary AK. An insight into the properties of Aegle marmelos pectin-chitosan cross-linked films. Int J Biol Macromol. 2013;52(1):7784.

34. Kowalonek J. Studies of chitosan/pectin complexes exposed to UV radiation. Int J Biol Macromol. 2017;103:515-24.

35. Recillas M, Silva LL, Peniche C, Goycoolea FM, Rinaudo M, Román JS, et al. Thermo- and $\mathrm{pH}$-responsive polyelectrolyte complex membranes from chitosan-gN-isopropylacrylamide and pectin. Carbohydr Polym. 2011;86(3):1336-43.

36. Alvarez-Lorenzo C, Blanco-Fernandez B, Puga AM, Concheiro A. Crosslinked ionic polysaccharides for stimuli-sensitive drug delivery. Adv Drug Deliv Rev. 2013;65(9):1148-71.

37. Neufeld L, Bianco-Peled $\mathrm{H}$. Pectin-chitosan physical hydrogels as potential drug delivery vehicles. Int J Biol Macromol. 2017;101:852-61.

38. Rampino $A$, Borgogna $M$, Bellich $B$, Blasi $P$, Virgilio $F$, Cesàro $A$. Chitosan-pectin hybrid nanoparticles prepared by coating and blending techniques. Eur $\mathrm{J}$ Pharm Sci. 2016;84:37-45.

39. Wu L, Wang H, Zhu XH, Hou YC, Liu WW, Yang GM, et al. Pectin-chitosan complex: Preparation and application in colon-specific capsule. Int J Agric Biol Eng. 2015;8(4):151-60.

40. Wusigale, Liang L, Luo Y. Casein and pectin: Structures, interactions, and applications. Trends Food Sci Technol. 2020;97(September 2019):391-403.

41. Rodriguez Patino JM, Pilosof AMR. Protein-polysaccharide interactions at fluid interfaces. Food Hydrocoll. 2011;25(8):1925-37.

42. Chang $\mathrm{C}$, Wang $\mathrm{T}$, Hu Q, Zhou M, Xue J, Luo Y. Pectin coating improves physicochemical properties of caseinate/zein nanoparticles as oral delivery vehicles for curcumin. Food Hydrocoll. 2017;70:143-51.

43. Li X, Fang Y, Al-Assaf S, Phillips GO, Jiang F. Complexation of bovine serum albumin and sugar beet pectin: Stabilising oil-in-water emulsions. J Colloid Interface Sci. 2012;388(1):103-11.

44. Wang T, Hu Q, Zhou M, Xia Y, Nieh MP, Luo Y. Development of "all natural" layerby-layer redispersible solid lipid nanoparticles by nano spray drying technology. Eur J Pharm Biopharm. 2016;107:273-85.

45. Baracat MM, Nakagawa AM, Casagrande R, Georgetti SR, Verri WA, De Freitas O. Preparation and characterization of microcapsules based on biodegradable polymers: Pectin/casein complex for controlled drug release systems. AAPS PharmSciTech. 2012;13(2):364-72.

46. Fahrurroji $A$, Thendriani $D$, Riza $H$. Hesperidin Hydrogel Formulation Using PectinChitosan Polymer Combination. Int J Pharm Pharm Sci. 2017;9(12):98.

47. Huang S, Tu Z cai, Sha X mei, Wang H, Hu Y ming, Hu Z zi. Gelling properties and interaction analysis of fish gelatin-low-methoxyl pectin system with different concentrations of Ca2+. Lwt. 2020;132(July). 
48. Shewan HM, Stokes JR. Review of techniques to manufacture micro-hydrogel particles for the food industry and their applications. J Food Eng. 2013;119(4):78192.

49. Fernández Farrés I, Moakes RJA, Norton IT. Designing biopolymer fluid gels: A microstructural approach. Food Hydrocoll. 2014;42(P3):362-72.

50. Wu B cheng, McClements DJ. Functional hydrogel microspheres: Parameters affecting electrostatic assembly of biopolymer particles fabricated from gelatin and pectin. Food Res Int. 2015;72:231-40.

51. Gupta B, Tummalapalli M, Deopura BL, Alam MS. Preparation and characterization of in-situ crosslinked pectin-gelatin hydrogels. Carbohydr Polym. 2014;106(1):312-8.

52. Shalini B, Ruban Kumar A. Preparation and characterisation of gelatin blend pectin encapsulated hydroxyapatite $(\mathrm{Ca} 10(\mathrm{OH}) 2(\mathrm{PO} 4) 6)$ nanoparticles using precipitation method. Mater Today Proc. 2019;8:245-9.

53. Silva DF, Favaro-Trindade CS, Rocha GA, Thomazini M. Microencapsulation of lycopene by gelatin-pectin complex coacervation. J Food Process Preserv. 2012;36(2):185-90.

54. Tummalapalli M, Berthet M, Verrier B, Deopura BL, Alam MS, Gupta B. Drug loaded composite oxidized pectin and gelatin networks for accelerated wound healing. Int J Pharm. 2016;505(1-2):234-45.

55. Gałkowska D, Długosz M, Juszczak L. Effect of high methoxy pectin and sucrose on pasting, rheological, and textural properties of modified starch systems. Starch/Staerke. 2013;65(5-6):499-508.

56. Ma YS, Pan Y, Xie QT, Li XM, Zhang B, Chen HQ. Evaluation studies on effects of pectin with different concentrations on the pasting, rheological and digestibility properties of corn starch. Food Chem. 2019;274(February 2018):319-23.

57. Carbinatto FM, De Castro AD, Cury BSF, Magalhães A, Evangelista RC. Physical properties of pectin-high amylose starch mixtures cross-linked with sodium trimetaphosphate. Int J Pharm. 2012;423(2):281-8.

58. Carbinatto FM, de Castro AD, Evangelista RC, Cury BSF. Insights into the swelling process and drug release mechanisms from cross-linked pectin/high amylose starch matrices. Asian J Pharm Sci. 2014;9(1):27-34.

59. Liu Y. Starch-pectin matrices for encapsulation of ascorbic acid. Food Sci Technol Dep. 2014;1:1-101.

60. Soares GA, Castro AD De, Cury BSF, Evangelista RC. Blends of cross-linked high amylose starch/pectin loaded with diclofenac. Carbohydr Polym. 2013;91(1):135-42.

61. Rezvanian M, Ahmad N, Mohd Amin MCl, Ng SF. Optimization, characterization, and in vitro assessment of alginate-pectin ionic cross-linked hydrogel film for wound dressing applications. Int J Biol Macromol. 2017;97:131-40.

62. Nining N, Elfiyani R, Wulandari E. Comparison eugenol and oleic acid as a plasticizer on characteristic of dextromethorphan hydrobromide film by solvent casting method. Pharm Sci Asia. 2021;48(2):139-46.

63. Dafe A, Etemadi H, Dilmaghani A, Mahdavinia GR. Investigation of pectin/starch hydrogel as a carrier for oral delivery of probiotic bacteria. Int $\mathrm{J}$ Biol Macromol. 2017;97:536-43. 
64. Long J, Etxeberria AE, Nand A V., Bunt CR, Ray S, Seyfoddin A. A 3D printed chitosan-pectin hydrogel wound dressing for lidocaine hydrochloride delivery. Mater Sci Eng C. 2019;104(June):109873.

65. Birch NP, Schiffman JD. Characterization of self-Assembled polyelectrolyte complex nanoparticles formed from chitosan and pectin. Langmuir. 2014;30(12):3441-7.

66. Islan GA, De Verti IP, Marchetti SG, Castro GR. Studies of ciprofloxacin encapsulation on alginate/pectin matrixes and its relationship with biodisponibility. Appl Biochem Biotechnol. 2012;167(5):1408-20.

67. Puga AM, Lima AC, Mano JF, Concheiro A, Alvarez-Lorenzo C. Pectin-coated chitosan microgels crosslinked on superhydrophobic surfaces for 5-fluorouracil encapsulation. Carbohydr Polym. 2013;98(1):331-40.

68. Cazorla-Luna R, Notario-Pérez F, Martín-Illana A, Ruiz-Caro R, Tamayo A, Rubio J, et al. Chitosan-based mucoadhesive vaginal tablets for controlled release of the anti-HIV drug tenofovir. Pharmaceutics. 2019;11(1).

69. Khurana R, Singh K, Sapra B, Tiwary AK, Rana V. Tamarindus indica pectin blend film composition for coating tablets with enhanced adhesive force strength. Carbohydr Polym. 2014;102(1):55-65.

70. Pandey S, Mishra A, Raval P, Patel H, Gupta A, Shah D. Chitosan-pectin polyelectrolyte complex as a carrier for colon targeted drug delivery. J Young Pharm. 2013;5(4) :160-6. 